\title{
Psychic Substance: A Meeting Point between Metaphysics \& Spirituality
}

\author{
MOHAMMAD ALI SHOMALI, QOM
}

The discussion of the human soul, its existence, nature, eternity and perfection occupies a focal position in Islamic philosophy. All Muslim philosophers concerned themselves with the subject of the soul. The most detailed and most important works on this subject are those of Kindi, Farabi, Ibn Sina, Ibn Rushd, Mulla Sadra (Sadr al-Din Shirazi) and 'Allamah Tabataba'i. Referring to different types of substance discussed in Islamic Philosophy, this paper focuses on psychic substance, or soul, and reviews the nature and faculties of the soul highlighting the main characteristics of psychic substances and what features distinguish them from other substances along with a discussion about happiness of the soul.

\section{Substance and its different types}

Muslim philosophers recognise two aspects of every contingent being: quiddity (nature or whatness) and existence (being). All quiddities are universal and it is only existence which individuates. In this regard, M. T. Misbah writes:

Another issue is the problem raised in Islamic philosophy of whether a universal may be individuated by means of specific accidents. Every accident in reality also has a whatness to which the mind attributes universality, and therefore it participates with whatnesses of that which has accidents in the need to be individuated. And this question can be repeated with regard to them, as to how they are to be individuated. How is the addition of a universal essence to cause the individuation of a universal essence of that which has accidents?

Finally, Farabi offered the solution that individuation is an essential requirement of entified existence. Every essence in reality is found to be individuated by existence. Specific accidents each of which is individuated by its own existence are considered mere signs of the individuation of the essence of that which has acci- 
dents, and cannot be truly considered the cause of the individuation."1

Quiddity (mahiyyah) is divided into substance (jawhar) and accident ('arad). The reason for this classification is that either a quiddity can exist in a locus (or subject) that has no need of it for existence or it can exist without being in a locus that does not need it for existing. ${ }^{2}$ The former is called "accident", such as quantity, quality and relation. The latter is called "substance", such as body that has no locus or form to exist in a locus or subject, while its locus is in need of it.

Now let us focus on substance. On the basis of an inductive survey, the metaphysicians normally first divide substance into five kinds. For example, Allamah Tabataba'i explicitly states that the five-part division of substance is based on induction and there is no rational argument that the number of types of substance cannot be more than five. ${ }^{3}$

- $\quad$ matter (maddah), a substance that possesses potentiality;

- form (surah), a substance that gives actuality to matter e.g., bodily form (al-surat al-jismiyyah) gives actuality to mater in respect to its three dimensions;

- $\quad$ body (jism), a substance that is extended in three dimensions;

- $\quad$ soul (nafs), a substance free of matter in its essence but connected with it in action;

- intellect ('aql), a substance that is free of matter both in its essence and in action.

It has to be noted that neither form, like bodily form, nor soul technically fall under the category of substance, though existentially they are substances. As far as I know, this is a distinction that has hardly been attended in Greek philosophy. For the Greeks either something was a substance or not. However, Muslim philosophers believe that something may fulfil the requirements for being a substance, but still not be of a species of which substance is a genus. This means that they are not like accidents in need of locus that does not need them for its existence. In other words, they are not like predicables or qualities of something else. Essentially the soul and bodily form can exist independently from the body or any locus, but yet, they are different from other types of substance.

Refuting the idea of reincarnation (tanasukh), Mulla Sadra in his AlAsfar makes a very important remark about the relation between soul and

\footnotetext{
${ }^{1}$ Misbah Yazdi 1999, lesson 24.

${ }^{2}$ For example, see Tabataba'i 2002 and 1981.

${ }^{3}$ Tabataba'i 1981, 93.
} 
body. He argues that unlike what most people think, it is the soul that carries and contains the body and not vice versa. The soul uses the body as an instrument to act and exercise its power as long as the soul has not developed into the status of complete independence wherein it will not need body at all. Since the soul is abstract (as we will argue later), there is no way of thinking of the physical body as container or carrier of the soul. ${ }^{4}$

The quiddities of the soul and bodily form are simple and therefore are not compounds of a genus (that is, substance) and differentia (the distinctive part in the essence or quiddity that distinguishes one type of substance from another).

Muslim philosophers such as Mulla Sadra and 'Allamah Tabataba'i have a sophisticated argument here. According to them, form and differentia (fasl) are identical in their reality and it is only the way we consider them that makes them different. On the other hand, we know that the differentia is simple and does not need in turn a genus and another differentia to come into existence; otherwise there would be an endless series of differentia. 'Allamah Tabataba'i puts the result as follows:

The inclusion of bodily form in this classification is an accidental one, for form is differentia negatively conditioned and the differentiae of substances do not fall under the category of substance, though the term substance may be predicable of it (in the sense of technical predication), as was seen in the discussion on quiddity. ${ }^{5}$

The same applies to 'soul'. ${ }^{6}$

\section{Soul}

Definition: As we saw earlier, soul is a substance which is free of matter in its essence but connected with it in action. Soul is a form for the body to which it belongs. A very typical definition of soul is that it is a primary perfection (kamal al-awwal) for a natural body capable of performing the secondary perfections (kamal al-thani) necessitated by this primary perfection. A primary perfection is what makes a thing what it is or what constitutes the essence or nature of something like its differentia or genus. For example, sensation and voluntary movement are essential elements for

\footnotetext{
${ }^{4}$ Shirazi 1378 A.H., vol. 9, 47.

5 Tabatabi'i 2002, section 5, part 5.

6 Tabatabi'i 2002, section 6, part 2. The author has a note here in the footnote: "The soul as such is form for a substantial species and the differentiae of substances do not fall under the category of substance".
} 
animals. Likewise, sensation, voluntary movement and the ability to think are essential elements or primary perfections for human beings. In contrast, a secondary perfection is an external quality that is accidental to the nature of the species or genus, such as touching for animals or writing for human beings.

\subsection{Parts of the soul}

Normally Muslim philosophers, like some of their Greek predecessors, have argued that there are different types and levels of the soul:

A: The non-rational soul: This consists of:

A.1: The plant soul: This is the soul at its lowest level. The plant soul is a primary perfection for an organic natural body inasmuch as this body can take nourishment, grow and reproduce. Since these qualities are shared by all living beings including human beings and other animals, the plant soul is shared by all of them. What makes a flower or tree different from us is not their possession of the plant soul, since we and plants share this type of soul. What makes us different is that we have something more. If an animal is in a vegetative state it means that is has lost its sensation and voluntary movement, but still has the essential qualities of the plants such as taking nourishment.

A.2: The animal soul: This type of soul is more developed and perfect than the plant soul. The animal soul is a primary perfection for an organic natural body inasmuch as this body has sensation and voluntary movement. Of course, this soul has all the above-mentioned qualities of the plant soul. What makes it different from the plant soul is that it has two more abilities: the ability for sensitive understanding and the ability for moving at will. The sensitive power has both external and internal senses. The external senses are touch, taste, smell, hearing and sight. The internal senses which are accepted by most Muslim philosophers are common sense, imagination and memory. Ibn Sina adds two more i.e. representational power and estimative power. The locomotive power is divided into that which causes movement and that which actually moves. Explaining the difference between these two, Shams Inati writes:

The former, the desiderative power, subdivides into the appetitive and the irascible. The appetitive causes movement toward what is imagined to be necessary or beneficial in the pursuit of pleasure. The irascible causes avoidance of what is imagined to be harmful or an impediment in the pursuit of dominance. The power 
that actually moves uses the nerves to relax the muscles at the demands of the appetitive power or tighten them at the demands of the irascible one. ${ }^{7}$

B: The rational soul: This type of soul is even more developed than the animal soul. The rational soul is a primary perfection for an organic natural body inasmuch as this body can act by rational choice and grasp universals. The rational soul is divided into:

B.1: The practical intellect: The practical intellect ('aql al-'amali) is responsible for understanding what is good for oneself, for family and for state. It must be noted that "intellect" or " "aql" here means human reason and is completely different from the intellect which was discussed earlier as an immaterial and entirely abstract substance. The practical intellect corresponds to the three disciplines which form practical wisdom (hikmah al'amaliyyah), i.e., ethics, home management, and politics. The practical intellect is the rational soul turning its face downward and attending to itself and the world around.

B.2: The theoretical intellect: The theoretical intellect is responsible for understanding universal concepts. This corresponds to the disciplines which form theoretical wisdom (hikmah al-nazariyyah) such as mathematics and metaphysics. The theoretical intellect is the rational soul turning its face upward, since universals are not to be found in the material world. According to a classification by Kindi, which is accepted by other Muslim philosophers, the theoretical intellect is divided into the following:

I the material intellect ('aql al-hayulani), which is empty and has the potentiality for grasping the intelligible forms or universals. As Ibn Sina has pointed out, the reason why this type of the intellect is called "material" is that it is potential and receptive just as matter is potential and accepts form. II the habitual intellect ('aql bil-malaka), which grasps universals and has the ability to use them but does not always do so.

III the actual intellect ('aql bi'l-fi'l), which grasps universals in actuality and is always ready to use them.

IV the acquired intellect ('aql al-mustafad). This is the highest level of human understanding, in which the theoretical intellect becomes able to acquire universals in the purest form.

This is a more traditional way of classifying different levels of the intellect. In a more articulated way of classification of different ranks of the intellect, 'Allamah Tabataba'i writes:

\footnotetext{
${ }^{7}$ Inati 1998.
} 
The metaphysicians mention four ranks of the intellect. One of them is that which is in a state of potentiality in relation to all intelligibles. It is called the material intellect on account of its being similar to [prime] matter in being devoid of intelligibles and its potentiality in relation to all forms. The second is the intellect by faculty ('aql bi al-malakah) which is the rank wherein it intellects self-evident concepts and judgements; for the knowledge of self-evident things precedes the knowledge of speculative matters. The third is the intellect in act which intellects speculative matters through the mediation of self-evident concepts and judgements, though some of them are based on the others. The fourth is the intellect which partakes of all self-evident and derived intelligibles corresponding to the realities of the higher and the lower realms by virtue of having present before it all of them and its consciousness of them in act. Thus it is a knowing world similar to the external world and is called acquired intellect ('aql al-mustafad). ${ }^{8}$

\subsection{The existence of the soul}

Despite some controversy over other types of substance, there seems to be no dispute among Muslim philosophers about the existence of psychic substances. Especially when it comes to human beings, they all admit that there is a principle in human beings which is different from physical body and is the main thing responsible for their life, movement through will and understanding. Of course, they may disagree in details and this makes their philosophical positions distinct. However, a very important issue for Muslim philosophers has always been to demonstrate the existence of the soul as an immaterial being which is independent from the body in its essence, though there are interactions between them and some kind of interdependence in their acts.

At the very beginning of his inquiry about the soul in the Shifa' (Healing), Ibn Sina argues for the existence of the animal soul from the fact that animals perceive and move with some degree of will. On the other hand, we know that physical bodies do not have will. Therefore, these acts must belong to a principle animals have other than their bodies. This principle is what is called soul.

What is more important to illustrate is the existence of the rational soul. However, this may be an easier task because we have first hand and immediate experience of the rational soul on the one hand, and the acts of the rational soul are more sophisticated and distinct from those of the body. Ibn Sina's example of the suspended man (rajul-e mu'allaq) is intended to prove that the rational soul is aware of itself apart from any body. Ibn Sina

\footnotetext{
${ }^{8}$ Tabatabi i 2002, section 11, part 5 .
} 
suggests supposing that you are physically and mentally healthy, your eyes are closed, your fingers are open, hands and feet are open so that they do not touch each other or your body, the weather to be exactly as warm as your body, in a quiet and dark place, standing on nothing. Should you be created suddenly in such a condition, Ibn Sina argues, certainly you would have a very clear and profound awareness of yourself, though you may totally be inattentive to your body and the material world around you. ${ }^{9}$ Of course, Ibn Sina does not consider this as a demonstration (burhan); rather he tries to refer us back to our conscience or intuitive knowledge.

In the Shifa', Ibn Sina also argues that the soul must be an incorporeal substance because intellectual thoughts themselves are indivisible. Salim Kemal articulates his argument as follows:

Presumably he means that a coherent thought, involving concepts in some determinate order, cannot be had in parts by different intellects and still remain a single coherent thought. In order to be a coherent single unity, a coherent thought must be had by a single, unified intellect rather than, for example, one intellect having one part of the thought, another soul a separate part of the thought and yet a third intellect having a third distinct part of the same thought. In other words, a coherent thought is indivisible and can be present as such only to an intellect that is similarly unified or indivisible. However, corporeal matter is divisible; therefore the indivisible intellect that is necessary for coherent thought cannot be corporeal. It must therefore be incorporeal, since those are the only two available possibilities. ${ }^{10}$

I think Ibn Sina's argument from the idea of indivisibility does not just refer to the fact that a consistent thought cannot be distributed among different intellects. It is rather more general. Neither the soul nor its qualities, such as knowledge, can be divided, even in respect to one person. You cannot refer to your reality as a person and say that the right side of my reality or the left side of my reality is so and so, while we know that material things can be divided into smaller parts which can also be divided into parts once more, ad infinitum, if the means were available. Elsewhere I have written:

They also knew that if a person lost a limb, he or she was essentially the same person, with a handicap. Their notions of themselves did not seem to suffer in the process. Thus many philosophers concluded that soul is independent from the body...

\footnotetext{
${ }^{9}$ Ibn Sina 1375 A.H., Al-Namat 3, chapter 1; Ibn Sina 1956, Al-Nafs, essay 1.

${ }^{10}$ Kamal 1998.
} 
As noted with the loss of limb example, philosophers knew that humans even after losing parts of themselves were the same. We all seem to have an understanding of ourselves as a whole, as something which is not divisible, and which is simple and not compound. When we get our hair cut, we do not feel any less afterwards. That which remains besides our body and is not on the floor of the barbershop is what we are after. ${ }^{11}$

To prove the existence of the soul as an immaterial being, Muslim philosophers such as 'Allamah Tabataba'i argue:

[W]e find in human souls the property of knowledge, and the intelligible forms are non-material, existing for the knower and being present for him. And had the knower not been non-material through his freedom from potentiality and his possession of pure actuality, there would be no sense in anything being present for him. Hence, the intelligent human soul is non-material. It is a substance because it is the form of a substantial species and the form of a substance is a substance, as explained above. ${ }^{12}$

Of course, there are more arguments used by Muslim philosophers to show that the soul is incorporeal.

\subsection{The eternity of the soul}

Muslim philosophers generally believed that the non-rational part is linked essentially to the body and therefore they agreed that the non-rational soul comes into existence simultaneously with body and that it may be destroyed after the destruction of the body.

In respect to the rational soul, philosophers such as Ibn Rushd, who believe that the rational soul is originally not separate from matter, contend that the whole human soul comes into existence and is eventually destroyed. People such as Kindi and Ibn Sina, who attribute non-materiality to the essence of the rational soul, assert that this soul has no end. Some, like Farabi, believed that the rational soul may or may not survive eternally. Shams C. Inati writes:

Al-Kindi and Ibn Sina, for example, strongly adhere to the view that all rational souls are indestructible because by nature they are simple. Al-Farabi reminds us that the reason for eternal existence is the rational soul's knowledge of the eternal aspects of the universe. From this he draws the conclusion, as did Alexander of

\footnotetext{
${ }^{11}$ Shomali 2006, 48.

${ }^{12}$ See Tabatabi'i 2002, section 6, part 7.
} 
Aphrodisias before him, that only those rational souls that have this knowledge at their separation from the body are indestructible. Other rational souls are eventually destroyed. Ibn Sina finds in the grasping of the universals the grounds for happiness, not the eternity of the soul. Ibn Rushd seems to hold that only the acquired intellect can be indestructible; but the acquired intellect, he argues (as does his teacher Ibn Bajja), is divine and numerically one in all. Ibn Rushd was attacked for this view because it denies eternal existence of individual souls. ${ }^{13}$

\subsection{Happiness of the soul}

The soul is a unity with all its parts working for one final end. Of course, each part of the soul may have its own lower ends as well. For example, the plant soul serves the animal and rational souls, but has its own aim to protect life with nourishment, growth and reproduction. Now the question arises: what is that final end?

Muslim philosophers believe that the ultimate end or happiness of the soul depends on its ability to separate itself from the demands of the body and to focus on grasping the eternal aspects of the universe. As we saw earlier, by reaching the state of the acquired intellect one becomes "a knowing world similar to the external world" ("aalam-an 'ilmiy-an mudaahiy-an lil-'aalam al-'ayni). This is a very typical formulation among Muslim philosophers. For example, Mulla Sadra says, "[through Hikmah] man becomes an intelligible world resembling the objective world and similar to the order of universal existence". ${ }^{14}$ Explaining how the soul can gain knowledge of all knowable subjects, 'Allamah Tabataba'i writes:

...the soul is non-material essentially, not in act; by virtue of its essential nonmateriality it intellects its own essence in act, but its actual attachment [to matter] necessitates its gradual transition from potentiality to act in accordance with different degrees of preparedness. And when it attains to complete non-materiality and is no more preoccupied with the regulation of the body's functions, it apprehends all knowables in the manner of non-differentiated knowledge, becoming an acquired intellect in act ('aql mustafad bi al-fi'l). ${ }^{15}$

Thus, Muslim philosophers aim at knowing and introducing God and the world of creation through concepts and conceptual arguments that are easy to access, understand and communicate for most people and, as said above, become "a knowing world similar to the external world". This does not

\footnotetext{
${ }^{13}$ Inati 1998.

${ }^{14}$ Shirazi 1967, 20.

${ }^{15}$ Tabatabi'i 2002, section 11, part 11.
} 
mean that they are only interested in theory and not in practice. A very important part of philosophical inquiry for them is related to practical disciplines, such as ethics, home management and politics. It should be noted that for them unlike most of their Greek predecessors ethics is very broad and deals with the subtle issues related to one's relation with God. Thus, for them a proper philosopher is one who knows the real world in a general way (that is, through universal concepts) and also knows what to do in the real world in respect to one's relation with oneself, family, society, state, nature and God. Knowledge including both the theoretical and the practical seems to be the ultimate end of philosophy as a discipline for some of the Greek predecessors of Muslim philosophers. For them whether someone acts according to what he learns through philosophy or not has nothing to do with philosophy as such. One may act immorally and still be a celebrity in philosophy. Perhaps the roots of this idea may be traced to remarks by Aristotle that knowledge and wisdom are not sufficient for leading a virtuous life and achieving felicity.

What about Muslim philosophers? Are they satisfied with just knowing the realities of the world and knowing what a proper course of action in certain circumstances is? It seems to me that for Muslim philosopherseven the Peripatetic ones-doing philosophy involved what I can formulate as: bearing witness to what you know and witnessing what you know in the real world. For example, the first Muslim philosopher, al-Kindi writes in his On First Philosophy:

Philosophy is the knowledge of the reality of things within people's possibility, because the philosopher's end in theoretical knowledge is to gain truth and in practical knowledge to behave in accordance with truth. ${ }^{16}$

I think here we find a shift. Instead of saying the end in practical knowledge is to know how to behave he says, "to behave in accordance with truth". The case of Ibn Sina is more significant. In his "Uyun al-Hikmah he suggests that philosophy or Hikmah is "the perfection of the human soul through conceptualization of things and judgment of theoretical and practical realities to the measure of human ability". ${ }^{17}$ In this definition he seems to suggest that philosophy is just about knowing theoretical and practical realities as much as possible. Of course, it is clear that he takes this by itself just one (and not all) perfection for the human soul, compared to those

\footnotetext{
${ }^{16}$ Cited in Nasr 1996.

${ }^{17}$ Ibid.
} 
who do not have such knowledge. Later in his life he distinguished between Peripatetic philosophy and what he called "Oriental philosophy" (a/Hikmat al-Mashriqiyyah). Oriental philosophy is not based on ratiocination alone but included realized knowledge. It has been suggested that Ibn Sina's idea of Oriental philosophy set the stage for the Illuminationist philosophy or Hikmat al-Ishraq of Suhrawardi. ${ }^{18}$ Interestingly, Ibn Sina in the last three sections (al-namat) of Al-Isharat wa al-Tanbihat presents a very nice and, indeed, a masterpiece on mysticism. A great commentator of $\mathrm{Al}$ Isharat wa al-Tanbihat, Nasir al-Din Tusi is his own monograph: Awsaf alAshraf gives a scholarly account of the spiritual journey towards God and different stages that a wayfarer has to go through to be able to meet God.

Therefore, it seems clear that Muslim philosophers saw a close relation between the theoretical aspect of rational soul and the practical aspect of it, between thinking philosophically and leading a virtuous life. In this regard Nasr writes:

This nexus, which is to be seen in all schools of earlier Islamic philosophy, became even more evident from Suhrawardi onward and the Hakim came to be seen throughout Islamic society not as someone who could only discuss mental concepts in a clever manner but as one who also lived according to the wisdom which he knew theoretically. The modern Western idea of the philosopher never developed in the Islamic world and the ideal stated by the Ikhwan al-Safa who lived in the fourth/tenth century and who were contemporary with Ibn Sina was to echo ever more loudly over the ages wherever Islamic philosophy was cultivated. The Ikhwan wrote, "The beginning of philosophy (falsafah) is the love of the sciences, its middle knowledge of the realities of existents to the measure of human ability and its end words and deeds in accordance with knowledge." (Rasa'il, I, Cairo, $1928)^{19}$

According to Suhrawardi and all later Islamic philosophers, Hikmah must be realized within one's whole being and not only mentally. Suhrawardi believed that a Hakim (sage) is one whose soul can ascend to the world of lights and, therefore, has achieved the purification of soul as well as the perfection of the theoretical faculty of the soul.

Mulla Sadra, the founder of transcendent philosophy, shows sympathy toward the conventional definition of philosophy among the Peripatetic philosophers in some of his works. For example, in the beginning of $\mathrm{Al}$ -

18 See Chapters 1 \& 17 of History of Islamic Philosophy edited by Sayyid Husayn Nasr and Oliver Leaman. It should be noted that in Arabic "Mashirq" and "ishraq" are from the same root "shuruq" meaning illumination or shining.

${ }^{19}$ Nasr 1996, 23. 
Asfar al-'Aqliyyah al-Arbi'ah he introduces philosophy as "the perfecting of the human soul to the extent of human ability through the knowledge of the essential reality of things as they are in themselves and through judgment concerning their existence established upon demonstration and not derived from opinion or through imitation". However, it is very clear from entire work that he is very much concerned with qualities of soul other than knowledge as well. In the first section of the same work which deals with being or existence, Mulla Sadra shows his concern about detachment from passions and purification of the soul from its material defilements. Indeed, Mulla Sadra, his contemporaries and most of his successors have very high esteem for philosophy and see genuine philosophers as the most perfect human beings standing in rank only below the prophets and Imams.

It should be noted that in Islamic philosophy the way to know God and the world is not restricted to conceptual knowledge. Supporting the idea of the Illuminationists, ${ }^{20}$ 'Allamah Tabataba'i argues for the possibility of the soul having immediate knowledge of its cause as follows:

That is so because the existence of the effect, as mentioned earlier, is dependent on the existence of the cause and is sustained by it; it is not independent of the cause. Hence, when the cause and the effect are non-material, the effect is present with all its being for the cause, without there being any barrier between them. It is known with immediacy to the cause through its existence itself. Similarly, when the cause and the effect are non-material, the cause is present with its existence for its effect, which is sustained by it, being independent through the independence of the cause, and there is no barrier separating them. Hence it is known to its effect with an immediate knowledge. ${ }^{21}$

Thus, theoretically it is possible for all human beings to have an immediate knowledge of God, our final cause. Now, the question arises why there are people who cannot find God. To be able to understand this better we should explore further the idea of "immediate knowledge". Immediate knowledge here means knowledge by presence (al- 'ilm al-huãuri) and that is when the object of knowledge, i.e., what is known, by itself is present to the subject of knowledge, i.e., the knower, and there is no resort to any conceptual image of the object to mediate between the two. In contrast, conceptual knowledge (al-'ilm al-husuli) is based on the concepts or images of the knowable. Therefore, what is primarily known is the image and

${ }^{20}$ The Illuminationist (Ishraqi) philosophers are those who took their inspiration from Sohravardi.

${ }^{21}$ Tabatabi i 2002, section 11, part 12. 
then through the image the knowable is known. Conceptual knowledge constitutes most of our knowledge, but it is subject to mistakes and illusion. Immediate knowledge admits no mistake, because there is no separation or distance between the knower and what is known. It is only when we try to interpret it and put it in a conceptual framework that we may make mistakes. For example, when I am feeling happy or hopeful or hungry this feeling is known immediately to me and cannot be mistaken. However, when I try to interpret it or explain what has caused this feeling I may make mistakes. I may really have such feeling without knowing what the true explanation for that is. Sometimes we may even not be able to describe our feelings or spiritual experiences by words.

In the case of immediate knowledge of God which is possible for all people, what may actually happen is that there may be some people who are so preoccupied with other things that their attention gets diverted from this knowledge to other things. It is also possible that some people may have this first hand experience of God but may not be able to read or interpret it in a proper way. Indeed, people like Ibn Arabi argue that no one has ever loved or worshiped anyone other than God. He says:

Nothing other than God is loved. He is what appears from whatever is beloved in the eyes of whoever loves. There is no being except that it loves. Thus the whole universe loves and is loved and all these go back to Him just as nothing has ever been worshipped other than Him since whatever a servant (of God) has ever worshipped has been so because of wrong imagination of deity in it; otherwise it would have never been worshipped. God the most High, says (in the Qur'an): 'and your Lord has commanded not to worship but Him.'(17:23) This is the case with love as well. No one has ever loved anything other than his Creator. However, He, the most High has hidden Himself from them under the love for Zaynab, Su'ad, Hind, Layla, dunya (this world), money, social position and all other beloved subjects in the universe. ${ }^{22}$

The highest perfection of soul depends on having immediate knowledge of God consciously and constantly. I think it is this kind of knowledge that is necessarily linked to purification of soul and living virtuously. To be able to see God through everything and then seeing everything through God is much different from the conceptual knowledge that there is a necessarily

\footnotetext{
${ }^{22}$ Heydarpoor, Mahnaz, Love in Christianity \& Islam cited and translated into English from Ibn Arabi, Al-Futuhat al-Makkiyyah, 1994, Vol. 2, 326. Ibn Arabi adds that: "mystics have never heard any poem or praise or the like but about Him (and they saw Him) beyond veils." (Ibid)
} 
existent being who is present everywhere and that everything is created by Him. Thus, as said above, if Muslim philosophers introduce God and the world of creation through concepts and conceptual arguments it is just because they are easier to access, understand and communicate for most people. Then every person needs to experience this in his life and that very experience cannot be communicated to anyone else.

\section{REFERENCES}

Heydarpoor, M. 2005 Love in Christianity \& Islam, London: New City, $2^{\text {nd }}$ edition. Ibn Arabi 1994 Al-Futuhat al-Makkiyyah, Beirut: Dar al-Fikr.

Ibn Sina 1375 A.H. Al-Isharat wa al-Tanbihat, Qom: Nashr al-Balagh.

- 1956 Al-Shifa', Cairo: Al-Matba'atul Amireyyah.

Inati, S.C. 1998 "Soul in Islamic Philosophy", in Routledge Encyclopaedia of Philosophy. Version 1.0, London: Routledge.

Kamal, S. 1998 "Ibn Sina", in Routledge Encyclopedia of Philosophy, Version 1.0, London: Routledge.

Misbah Yazdi, M. T. 1999 Philosophical Instructions, A. Sarvdalir and M. Legenhausen, trs., Birmingham: Global Publications.

Nasr, S. H. 1996 "The meaning and concept of Philosophy in Islam" in History of Islamic Philosphy, London: Routledge.

Shirazi, Sadr al-Din 1378 A.H. Al-Asfar al-Aqliyyah al-Arbi'ah, Qom: Mostafavi.

- 1967 Al-Shawihid a/-Rububiyyah, ed. S. J. Ashtiyani, Mashhad.

Shomali, M A. 2006 Self-knowledge, Qom: Jami' at al-Zahra, $2^{\text {nd }}$ edition.

- 2001 Ethical Relativism: An Analysis of the Foundations of Morality, London: Islamic College for Advanced Studies.

Tabataba'i, S. M. H. 2002 Bidayat al-Hikma, trans. A. Q. Qaraei, London: Islamic College for Advanced Studies.

- 1360 / 1981 Nihayat al-Hikma, Qom: Jami`at al-Mudarresin. 